Reprod. Nutr. Dévelop., 1985, 25 (5), 977-991.

\title{
The regulation of glucocorticosteroid secretion during the perinatal period
}

\author{
M. DALLE, P. PRADIER, P. DELOST
}

Laboratoire de Physiologie Animale et U.A. C.N.R.S. 041123

Université de Clermont-Ferrand II, B.P. 45, 63170 Aubière, France.

Summary. The regulation of adrenal activity during the perinatal period raises different experimental problems; studies are often limited and their conclusions vary with the species studied. During the perinatal period, the profile of the ratio of adrenal weight to body weight reaches a minimum earlier the more mature is the species; this minimum occurs before birth in sheep, at birth in guinea-pigs and 10 days after birth in mice.

In mature species, fetal plasma cortisol is higher than that of the mother; it rises sharply near term. In other species, maternal plasma cortisol remains higher than that of the fetus which also rises during the days before birth. In all species, the fetal adrenal is activated concomitantly with a sharp increase of the action of corticosteroid binding globulin on fetal plasma. The origins of this protein in the fetal plasma and the regulation of its concentration are topics of actual research. Before birth, placental transfer of cortisol increases regularly and slowly. During the perinatal period it is demonstrated that fetal catabolism of cortisol augments up to the adult level independently of changes in hormone secretion around birth.

Fetal and neonatal endocrinology deals with the functioning and physiological role of the endocrine glands during perinatal development. However, this period does not connote a steady state and covers several successive physiological stages in which glucocorticosteroids play an important role. Problems concerning the adrenal cortex are multifarious : 1) How do the adrenocortical cells become specialized during embryonic life ? 2) When are hormones first released into the circulation ? 3) What is the system controlling hormonal secretion at each developmental stage ? 4) How can perinatal changes in plasma hormone concentrations (including the maternal and fetal parts and the role of the placenta) be explained? 5) Where are the hormones catabolized ? 6) What is the origin of the plasma protein binding the corticosteroids in fetal and neonatal plasma?

Although there are an extensive number of publications, information is scattered. Recent efforts have been made in man and a few other species, but 
species differences induce divergent developmental patterns so that studies frequently fall into several groups that include :

1) Small laboratory animals with a short period of gestation (mice, rats, rabbits) ; these have been used in oft-reviewed physiological experim ,nts (Jost, 1954, 1957, 1966).

2) Humans in which gestation is relatively long and in which fetal endocrine processes are protracted over several months. Since ethical considerations preclude the study of the human fetus in late gestation, different monkey species have been utilized to investigate the mechanisms of adrenal regulation in the perinatal period reviewed by Jaffe et al., 1979, Seron-Ferré et al., 1978, Challis et al., 1978. Indeed, the monkey adrenal gland is histologically very similar to the human gland, with a well-developed fetal zone in the adrenal cortex.

3) Lamb and calf fetuses that are heavier at birth and more mature than human fetuses. Surgical procedures have been practiced and fetal blood vessels catheterized over several weeks in order to investigate in vivo metabolism (Wintour et al., 1975). In these species, the induction of parturition by the fetal adrenal gland has been extensively described and reviewed (Liggins et al., 1973). 4) Guinea-pigs : these laboratory animals present a relatively long gestation period with fetuses large enough to permit fetal surgical procedures and vessel catheterization. Moreover, the guinea-pig placenta appears to be very active and broadly resembles that of women (Duval, 1889 ; Myers et al., 1936 ; Kaufmann and Davidoff, 1977).

Furthermore, the guinea-pig has the highest ratio of adrenal weight to body weight of any animal (Cuvier, 1846), and it is the only non-primate mammal capable of synthesizing its own ascorbic acid. In contrast with the human fetal adrenal cortex, in which the fetal zone is very large and degenerates slowly after birth, the guinea-pig adrenal cortex already appears capable in early gestation of a steroid biosynthesis similar to that of the adult gland.

The chronological events of the perinatal adrenocortical function throughout development need to be investigated in other species, remembering that the comparison of one species to another and of developmental patterns in terms of fractioned gestational time have no physiological meaning.

Recent studies on the binding, metabolism and secretion of glucocorticosteroids which attempt to explain the regulation of steroid secretion during the perinatal period are reviewed in this paper that is principally based on our own experiments in mice, guinea-pigs, lambs and calves.

\section{Studies on adrenal growth}

In the mouse, perinatal changes in adrenal weight in relation to body weight are characterized by a regular, sharp decrease between days 17 prepartum and 10 days postpartum. During this period, the adrenal weight of the mothers in relation to body weight is similar to values found in 10-day old pups and higher than that of non-pregnant adults (Gay, 1976). 
The growth allometry coefficients of guinea-pig adrenal gland are also around 0.60 during the perinatal period (Dalle, 1982). The adrenal weight of the mothers is high $(0.85 \mathrm{~g} / \mathrm{kg} v s 0.40 \mathrm{~g} / \mathrm{kg}$ for non-pregnant females) during this period with a peak value $(1.25 \mathrm{~g} / \mathrm{kg})$ at birth. The ratio between adrenal weight and body weight $\left(0.15 .10^{-3}\right)$ appears to be approximately similar among most mammals ; adrenal weight probably bears a more direct relationship to the surface area of the animal rather than to body weight. The guinea-pig is a well-known exception with a relatively high adrenal weight for its body size (Cuvier, 1846); however, as in mice, adrenal growth is diminished during the perinatal period in this species as in humans (Bernirschke, 1970) and rats (Cohen et al., 1971). In all these species, this could be due to a decrease in the stimulatory activity of the pituitary during this perinatal period, as demonstrated in rats (Dupouy and Chatelain, 1981) and in guinea-pigs (Jones and Roebruck, 1980), species in which the fetal adrenal gland might be relatively unresponsive to ACTH in vivo because of an inhibitory effect of circulating, high-molecular weight, ACTH-like peptides. Our study in this species confirmed the data of Wüstenfeld and Kattner (1968) who found small and constant cell nucleus diameters in the zona fasciculata of the adrenal gland of fetal guinea-pigs near term. Indeed, the volume and the percentage of the zona fasciculata decreased during this period from $80 \%$ on day 60 of gestation to $71 \%$ at birth. After birth, the zona fasciculata grew regularly until day $10(85 \%)$ when it reached a value similar to that of the adult gland (fig. 1) (Dalle and Delost, unpublished). In contrast to these two species, other mammals are characterized by a rise in adrenal growth during the perinatal period. In sheep (Comline and Silver, 1961), pigs (Dvorak, 1972), goats (Currie and Thornburn, 1977) and calves (Boshier et al., 1980 ; Richet et al., 1984) the weight of the

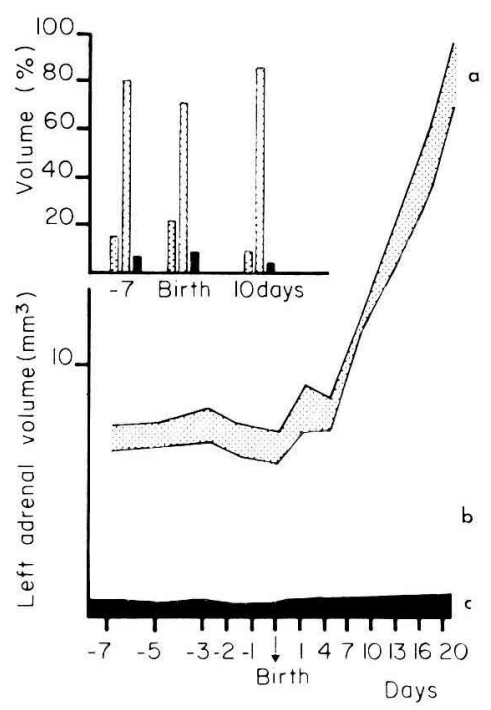

FIG. 1. - Perinatal profile of the volume of the guinea-pig adrenal gland and of its different zones (glomerulosa : a ; fasciculata : b ; medullary: c) and of their relative percentages (glomerulosa : $\because$; fasciculata : 
adrenal glands increases strikingly during the last days of gestation. Species differences in the adrenal weight profile appear around birth (fig. 2). In mice, guinea-pigs, rats and humans, the approach of birth is not concomitant with profound changes in adrenal activity, and the maturation of this gland seems to be delayed over a varying number of days during the perinatal period. This contrasts with species characterized by prenatal adrenal growth and concomitant rising levels of cortisol and ACTH (Rees et al., 1975). These changes could be essential to the full development of the prepartum surge of adrenal activity which appears to be a major factor in determining the timing of parturition (Liggins et al., 1973 ; Bassett and Thornburn, 1969).

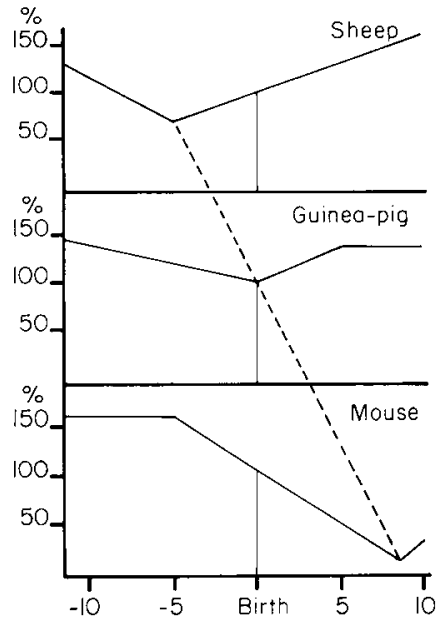

FIG. 2. - Compared perinatal changes in relative adrenal weight in sheep, guinea-pig and mouse expressed in \% of the birth values.

\section{Perinatal changes in glucocorticosteroid concentrations}

Although the mammalian neonate can exist independently outside the uterus, the degree of competence of neonatal physiological systems, and especially the endocrine systems, differs considerably among species. While differences are observed in adrenal growth, other changes in peripheral blood hormone levels can also be demonstrated. Indeed, the profile of plasma concentrations reflects the integration of several parameters, and a comparison between maternal and fetal values gives further information on the ability of the adrenal to secrete hormones during the perinatal period. Figure 3 shows the maternal, fetal and neonatal plasma corticosteroid levels obtained in our laboratory. In species in which fetal adrenal activity is involved in parturition, it is clear that fetal cortisol levels are much higher than maternal values (cows: Comline et al., 1974 ; sheep : Liggins et al., 1973 ; goats : Currie and Thornburn, 1977 ; pigs: Fèvre, 1975). On the other hand, species in which birth is associated with relative quiescence of the 


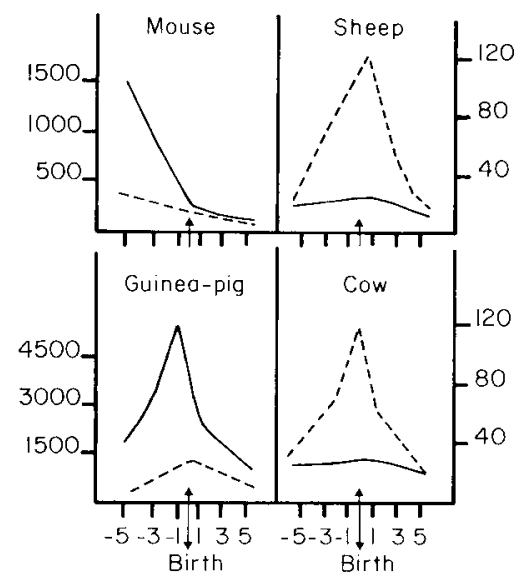

FIG. 3. - Changes in the g/ucocorticoid leve/s $(\mathrm{ng} / \mathrm{ml})$ in the maternal (-) and fetal and neonatal (----.- I plasma of mouse, guinea-pig, sheep and cow.

adrenal gland are characterized by higher maternal plasma glucocorticosteroid levels than those of the fetus (mice : Dalle et al., 1978 ; guinea-pigs : Dalle and Delost, 1976 ; humans : Jolivet et al.; 1974 ; monkeys : Jaffe et al., 1978). In the first group above, perinatal changes in corticosteroids are marked by a sharp rise in the first few days before birth but no similar changes occur in the mothers; in the second group, maternal steroids can contribute to the fetal corticosteroid production rate. This maternal influence on the fetal pituitary-adrenal function depends upon the extent of the corticosteroid-binding capacity of the plasma proteins, the rate of placental transfer and the activity level of the key placental enzymes.

\section{Plasma corticosteroid binding in mother, fetus and newborn}

Little information is available on the ontogeny of fetal transcortin and discrepancies occur in the literature concerning its regulatory system and intensity. This is due to differences in methodology and the expression of values. Close correlation of fetal and maternal binding capacity has been observed in different species (mice : Savu et al., 1977) ; rabbits: Gala and Westphal, 1967 ; rats : Van Baelen et al., 1977, Martin et al., 1977 ; guinea-pigs : Dalle et al., 1980 ; Jones and Roebruck, 1980 ; humans : Aarskog, 1965 ; baboons : Oakey, 1974). This contrasts with sheep (Fairglough and Liggins, 1975) in which fetal corticosteroid-binding globulin (CBG) capacity increases at the end of gestation since maternal values do not change (Paterson and Hill, 1967). Maternal origin has been suggested (Savu et al., 1977), and this possibility remains to be demonstrated in species such as rodents whose fetus is in a yolk sac vascularized by maternal and fetal vessels which make anastomosis. Brambell et al. (1951) demonstrated the transfer of immune proteins in rabbits by this route. As for 
progesterone binding protein (PBP), the placental synthesis of CBG has been proposed by Seal and Doe (1967); nevertheless, the fetal liver can synthesize CBG (Martin and Gasc, 1979), probably under hormonal control (Koch, 1969), but with a system different from that of adult patterns in which oestrogen stimulation is well-known (Westphal, 1971), and unlike the system initiating CBG activity in young animals in which thyroxine plays an essential role (D'Agostino and Henning, 1982). Furthermore, Ballard et al. (1982) have demonstrated an accelerated increase in both CBG and total proteins in fetal lambs just before term and preceding the rise in plasma cortisol. These authors suggest that the earlier elevation of $C B G$ levels protects the fetus from increases in free cortisol that could initiative premature labor since biological activity may be largely associated with unbound cortisol. Indeed, labor is initiated later when the increase in free cortisol exceeds that of total cortisol due to the saturation of CBG binding sites. In this period, a reversible control of fetal liver enzymes by cortisol may partly regulate CBG release (Challis et al., 1985). At birth, a precipitous decline in CBG in neonatal monkeys correlates with a drop in plasma oestrogens (Beamer et al., 1972). Ballard et al. (1982) showed that an intact fetal pituitary is required for the normal development of CBG capacity but the pituitary hormone that directly or indirectly causes accumulation of fetal plasma CBG is not known at present. In newborn animals, the picture is similar in all studied species in that CBG activity decreases. Thus, Hadjian et al. (1975) in human neonates and Beamer et al. (1972) in monkeys showed that CBG values decrease in the neonate before a slight rise to adult values. Dalle et al. (1980) reported the same profile in guineapigs, adult values being reached during sexual maturation (El Hani et al., 1980). All these studies seem to confirm the recent data of Challis et al. (1985) which suggest that cortisol might be the factor regulating the corticosteroid binding

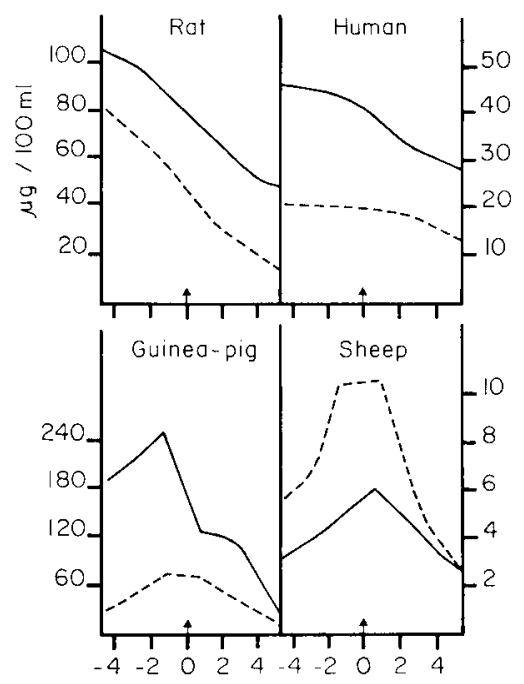

FIG. 4. - Perinatal changes in CBG capacity in the plasma of mother (-), fetus and newborn (-.---) in the guinea-pig, rat, man and sheep. 
capacity of fetal and neonatal plasma. Indeed, plasma CBG is well correlated to plasma cortisol levels.

After birth, there is a decrease in plasma cortisol levels in many mammals ; in guinea-pigs the plasma cortisol levels decrease over a 10-day period (Dalle and Delost, 1974; Malinowska and Nathanielsz, 1974) as in rats and rabbits (Malinowska et al., 1972), lambs (Paisey and Nathanielsz, 1971), calves (Richet et al., 1984), human infants (Stevens, 1970 ; Kauppila et al., 1978), mice (Dalle et al., 1978), fowls (Khaldoun, 1977) and macaques (Robinson and Bridson, 1978).

The profile of $\mathrm{CBG}$ in neonatal plasma parallels this decrease.

Furthermore, a half-life T1/2 value of about 5 days for $C B G$ has been measured in sheep (Ballard et al., 1982), rats (Koch et al., 1969) and humans (Sandberg et al., 1964). Our results in newborn guinea-pigs confirm these postnatal changes in CBG (Dalle et al., 1980). Figure 4 shows comparative changes in the capacity of CBG to bind cortisol in maternal and fetal plasma during the perinatal period. Thus, in most species studied, there is a rise in free corticosteroid levels before and at birth, beginning during the sequential events preceding term and after the rise in total corticoids which follows that of $C B G$ capacity. If CBG protects corticosteroids from catabolism, the rise in free cortisol is also partly due to relatively immature hepatic catabolism, and the development of steroid catabolism may influence the level of plasma corticoids.

\section{Perinatal metabolism of corticosteroids}

Bongiovanni et al. (1958) have shown in humans that cortisol half-life is very much prolonged in the newborn infant, and Migeon and Baltimore (1959) have demonstrated that in the neonatal period the enzyme systems involved in the catabolism of cortisol are less active than in adults. Animal experiments have confirmed the low maturation of steroid metabolism during growth and partly explained the changes in glucocorticosteroid levels during neonatal life. Thus, the progressive establishment of corticosteroid metabolism by liver enzymes, that parallels the development of CBG activity, is an additional parameter involved in the regulation of corticosteroid concentrations. Shapiro et al. (1971) in rats confirmed that the metabolic half-life of plasma corticosterone is considerably prolonged during early postnatal life due to differences in liver enzyme activities. For instance, liver $\Delta_{4}$-hydrogenases have very little activity in neonatal rats (Koch, 1969) or in neonatal rabbits (Sereni et al., 1966). In newborn guinea-pigs, the glucocuronide conjugating system is defective (Brown and Zuelzer, 1958), and Dalle et al. (1985) have demonstrated that, in this species, cortisol metabolism depends on its degradation in the liver and on its distribution volume. This volume develops during the neonatal period (Dalle et al., 1985), paralleling body growth after 10 days postpartum, but more slowly before this stage. Fetal steroid metabolism cannot be investigated without keeping in mind maternal influence on fetal plasma corticosteroid levels. Furthermore, the role of placental enzymes in steroid metabolism has been well documented in several species, especially in humans (Diczfalusy, 1962, 1969 ; Murphy, 1981) but it is not easy to 
experimentally evaluate the transplacental transfer of glucocorticosteroids, and results vary widely with the species and stage of gestation.

Experiments have simultaneously investigated placental transfer and corticosteroid metabolism in the feto-maternal unit. These works used the calculation system presented by Gurpide (1972) (fig. 5).

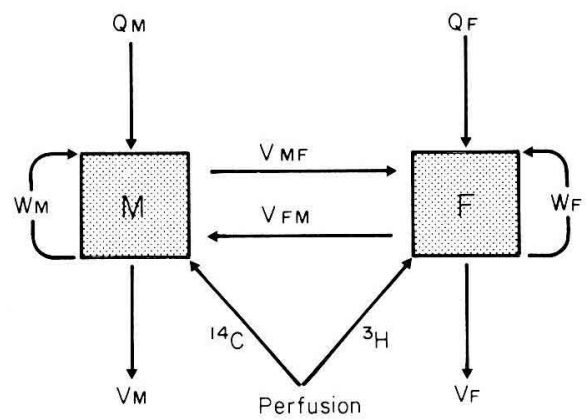

FIG. 5. - Diagram illustrating the fate of cortisol in fetal (F) and maternal (M) circulation (from Gurpide, 1972).

Thus, parameters of maternal and fetal adrenal activity may be calculated after simultaneous infusion of ${ }^{3} \mathrm{H}$-cortisol to the fetus and of ${ }^{14} \mathrm{C}$-cortisol to the mother or, as we did, by a single infusion of ${ }^{3} \mathrm{H}$-cortisol to different groups of mothers and fetuses of the same age (Dalle and Delost, 1978); radioactive cortisol was equilibrated between secretion and metabolism as the endogenous pool in both compartments. In species such as sheep, monkeys and guinea-pigs, in which fetal blood vessels are easy to cannulate, the results are difficult to compare and summarize since the stages of gestation are different. A broadly equivalent study performed in six women at term (Beitins et al., 1973) showed that $25 \%$ of the fetal cortisol was of maternal origin and that $90 \%$ of the cortisone was also of the same origin. Fetal cortisone concentration was equivalent to that in plasma cortisol (Hillman and Giroud, 1965 ; Murphy and Diez d'Haux, 1972 ; Dormer and France (1973), although fetal as maternal adrenal secretion was negligible. This high level of fetal plasma cortisone is explained by the very low binding of plasma cortisone to transcortin and by the high activity of the $11 \beta$-dehydrogenase enzyme system in the human placenta which converts maternal cortisol to fetal cortisone (Osinski, 1960 ; Villee et al., 1961 ; Goldkrand et al., 1976).

We demonstrated a similar process in guinea-pigs (Dalle and Delost, 1976) showing that the cortisone/cortisol ratio in newborn plasma might be used as an index of adrenal maturity.

The origin of fetal corticosteroids was investigated and their metabolism measured by infusing radioactive cortisol to pregnant guinea-pigs or to their fetuses.

At the end of gestation, $90 \%$ of the fetal cortisol was of maternal origin ; the secretion rate of fetal adrenal was very low as was metabolism. The value of the metabolic clearance rate (MCR) of cortisol in the mothers was found to be 


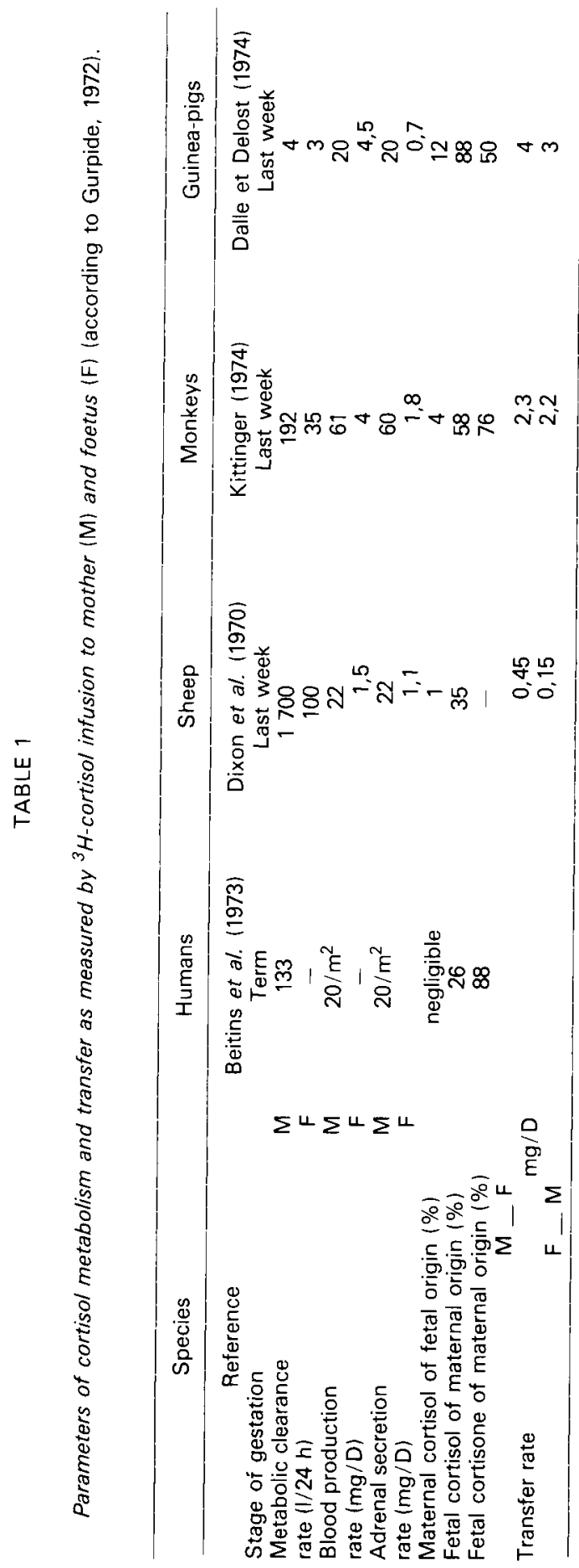

Reproduction, Nutrition, Développement $n^{\circ}$ 5-1985. -10 
lower than in non-pregnant females due to the high levels of CBG which protected the cortisol against metabolism. In the fetus, cortisol MCR was lower than maternal MCR but higher than in newborns. The dissociation of fetal MCR into placental MCR and true fetal MCR gives values for this latter parameter equivalent to those measured in newborns. In guinea-pigs, cortisol MCR remained low throughout the perinatal period and up to 10 days postpartum (Dalle et al., 1983). In pregnant ewes, cortisol MCR remained high as in nonpregnant animals (Beitins et al., 1969; Dixon et al., 1970) because of the low CBG level. The maternal contribution to fetal cortisol was about 25 to $45 \%$. Thus, fetal plasma cortisol remained low until a few days before birth and then rose, showing that adrenal development in sheep is independent of the dam's influence. In monkeys, pregnancy did not alter cortisol MCR (Pepe et al., 1976) and more than half of the total cortisol found in the fetal circulation was derived by transfer from the maternal circulation (Kittinger, 1974 ; Mitchell et al., 1981). This study confirmed that the factors regulating the fetal cortisol concentration involved placental metabolism and the rates of the transplacental passage of cortisol.

This review does not pretend to be complete, although its bibliography is extensive. Our aim was to present a clear picture of the parameters regulating glucocorticosteroid secretion during the perinatal period. The review has been limited to plasma levels, adrenal secretion, plasma protein binding, cortisol metabolism and placental transfer and does not include pituitary influence and the biochemical maturation of adrenal cells which are discussed by colleagues in this symposium.

\section{Conclusion}

In normal physiological conditions just before birth, the maturity of the adrenal is correlated with the maturity of the whole animal and the secretion of glucocorticosteroids by the fetal adrenal may depend on the anatomy of the placenta. The increasing role of the fetal adrenal in glucocorticosteroid levels parallels a relative closure of the placental barrier since the fetal adrenals remain quiescent in species in which the placenta permits considerable maternal transfer of cortisol, according to the recent hypothesis of Challis et al. (1985). We propose that fetal cortisol induces fetal hepatic synthesis of its own binding proteins up to a level that can protect fetal organs from premature maturation until the last days of gestation when the liver may give preference to other functions such as glycogen storage. Thereafter, the neonatal liver cannot synthesize binding proteins for several days, this function not being essential to adaptation to neonatal life that requires more important changes in which the adrenal is not implicated.

The protection of the fetal organ from high concentrations of free corticoids also depends on the intensity of corticoid metabolism in the fetus or in the placenta. Indeed, the fetus fails to metabolize corticosteroids intensely enough to be protected from the sudden rise in corticoid levels induced by drug administration or by stress in the mother. 
A study of young submitted to high levels of corticoids after maternal stress has shown that they cannot respond to stress, and this is an important restriction in respect to viability in an independent life (Dalle et al., unpublished data).

Réunion d'Endocrinologie de l'Association des Physiologistes, Clermont, 23-24 Avril 1985.

Résumé. Régulation de la sécrétion des glucocorticostéroïdes au cours de la période périnatale.

La régulation de l'activité du cortex surrénal au cours de la période périnatale pose différents problèmes expérimentaux et les travaux relatifs à ce sujet sont souvent limités, donnant lieu à des interprétations qui varient avec les espèces étudiées. Lorsqu'on compare les études pondérales sur la surrénale au cours de la période périnatale, on observe que le poids surrénalien, rapporté au poids corporel, passe par un minimum d'autant plus précoce que l'espèce est plus mature au point de vue corporel (ce minimum se situe avant la naissance chez l'agneau, à la naissance chez le cobaye, $10 \mathrm{j}$ après chez la souris).

Chez les espèces matures, la cortisolémie fœtale, supérieure à celle de la mère, augmente fortement à l'approche du terme. Dans d'autres espèces, la cortisolémie maternelle reste supérieure à celle du fœetus; elle augmente également dans les jours qui précèdent la naissance. Dans tous les cas, il y a une activation de la surrénale fotale et une augmentation de la capacité de liaison de la "Corticosteroid Binding Globulin " (CBG) dans le plasma fœtal. L'origine de cette protéine chez le fœtus et la régulation de son niveau plasmatique sont encore controversées. Enfin, il y a une augmentation lente et régulière des transferts placentaires et de l'intensité du catabolisme du cortisol au cours de la période périnatale, indépendante des modifications qui se produisent à la naissance dans les sécrétions hormonales.

\section{References}

AARSKOG D., 1965. Cortisol in the newborn infant. Norvegian Monographs on Medical Science, p. 13. Scandinavian University Books.

BALLARD P. L., KITTERMAN J. A., BLAND R. D., CLYMAN R. I., GLUCKMAN P. D., PLATZKER A. C. G., KAPLAN S. L., GRUMBACH M. M., 1982. Ontogeny and regulation of - corticosteroid-binding globulin capacity in plasma of fetal and newborn lambs. Endocrinologv, 110, 359-366.

BASSETT J. M., THORBURN G. D., 1969. Foetal plasma corticosteroids and the initiation of parturition in the sheep. J. Endocr., 44, 285-286.

BEAMER N., HAGEMENAS F., KITTINGER G. W., 1972. Protein-binding of cortisol in the rhesus monkey (Macaca mulatta). Endocrinology, 90, 325-327.

BEITINS I. Z., BAYARD F., ANCES I. G., KOWARSKI A., 1973. The metabolic clearance rate, blood production, interconversion and transplacental passage of cortisol and cortisone in pregnancy near term. Pediat. Res., 7, 509-519.

BEITINS I. Z., KOWARSKI A., SHERMETA D. W., DELEMOS R. A., MIGEON C. J., 1969. Fetal and maternal secretion rate of cortisol in sheep : diffusion resistance of the placenta. Pediat. Res., 4, 129-134.

BERNIRSCHKE F., 1970. Vergleichende Endokrinologie der Fetalzeit. Symp. dtsch. Endokrin., 16, 11-20.

BONGIOVANNI A. M., EBERLEIN W. R., WESTPHAL M., BOGS T., 1958. Prolonged turnover rate of hydrocortisone in the newborn infant. J. clin. Endocrinol. Metab., 18, 1127-1139.

BOSHIER D. P., HOLLOWAY H., LIGGINS G. C., 1980. Growth and cytodifferentiation of the fetal lamb adrenal cortex prior to parturition. J. Anat., 130, 97-111. 
BRAMBELL W. F. R., HEMMINGS W. A., HENDERSON M., 1951. Antibodies and Embryos, The Athlone Press, University of London.

BROWN A. K., ZUELZER W. W., 1958. Studies on the neonatal development of the glucuronide conjugating system. J. clin. Invest., 37, 332-340.

CHALLIS J. R. G., GLICKMAN J. A., SOCOL M., MURATA Y., MANNING F. A., 1978. Control of fetal corticosteroid production in human and primate pregnancy. Endocrinologie prénatale et parturition. Les Colloques de I'INSERM, INSERM, vol. 77, 23-38.

CHALLIS J. R. G., NANCEKIEVILL E. A., LYE S. J., 1985. Possible role of cortisol in the stimulation of cortisol binding capacity in the plasma of fetal sheep. Endocrinology, 116, 1139-1144.

COHEN A., DUPOUY J. P., JOST A., 1971. Influence de I'hypothalamus sur I'activité corticostimulante de l'hypophyse fœtale du rat au cours de la gestation. C. R. Acad. Sci. (D), Paris, 273, 883-886.

COMLINE R. S., HALL L. W., LAVELLE R. B., NATHANIELSZ P. W., SILVER M., 1974. Parturition in the cow : endocrine changes in animals with chronically implanted catheters in the foetal and maternal circulation. J. Endocr., 63, 451-472.

COMLINE R. S., SILVER M., 1961. The release of adrenaline and noradrenaline from the adrenal glands of the fetal sheep. J. Physiol. (Paris), 156, 424-444.

CURRIE W. B., THORNBURN G. D., 1977. Parturition in goats : studies on the interactions between the foetus, placenta, prostaglandin $F$ and progesterone before parturition, at term or at parturition induced prematurely by corticotrophin infusion of the foetus. J. Endocr., 73, 263278.

CUVIER G., 1846. Leçons d'Anatomie comparée, 2e ed. par DUVERNAY, T. VIII, Paris.

DALLE M., 1982. La fonction glucocorticoïde au cours des périodes prénatale et postnatale chez la mère, le fœtus et le nouveau-né de Cobaye. Th. Doct. ès-sci. d'Etat, Univ. Clermont-Ferrand, $235 \mathrm{pp}$.

DALLE M., DAUPRAT P., AUROUSSEAU B., BAUChART D., DELOST P., 1985. Influence of psychosomatic stress in pregnant guinea-pig on fetal lipid metabolism. J. dev. Physiol., (sous presse).

DALLE M., DELOST P., 1974. Changes in the concentrations of cortisol and corticosterone in the plasma and adrenal glands of the guinea-pig from birth to weaning. J. Endocr., 63, 483-488.

DALLE M., DELOST P., 1976. Plasma and adrenal cortisol concentrations in foetal, newborn and mother guinea-pigs during the perinatal period. J. Endocr., 70, 207-214.

DALLE M., DELOST P., 1978. Foeto-maternal production and transfer of cortisol during the last days of gestation in the guinea-pig. J. Endocr., 82, 43-51.

DALLE M., DELOST P., 1980. Maturation of glucocorticoid activity in the fetal guinea-pig during the end of gestation. Reprod. Nutr. Dévelop., 20, 277-286.

DALLE M., EL HANI A., DELOST P., 1980. Changes in cortisol binding and metabolism during neonatal development in the guinea-pig. $J$. Endocr., 85, 219-227.

DALLE M., GIRY J., GAY M., DELOST P., 1978. Perinatal changes in plasma and adrenal corticosterone and aldosterone concentrations in the mouse. J. Endocr., 76, 303-309.

DALLE M., PRADIER P., DELOST P., 1983. The conversion of cortisol into its principal metabolites, their tissular concentrations and transplacental transfer during ${ }^{3} \mathrm{H}$-cortisol perfusion of mother and fetal guinea-pigs. Steroids, 42, 511-523.

D'AGOSTINO J., HENNING S. J., 1982. Postnatal development of corticosteroid-binding globulin : Effects of thyroxine. Endocrinology, 111, 1476-1482.

DICZFALUSY E., 1962. Endocrinology of the foetus. Acta obstet. gynecol. scand., suppl. 41, 1, 4585.

DICZFALUSY E., 1969. Steroid metabolism in the human foeto-placental unit. Acta endocrinol., 61, 649-664.

DIXON R., HYMAN A., GURPIDE E., DYRENFURTH I., COHEN A., BOWE E., ENGEL T., DANIEL S., JAMES S., VANDEWIELLE R., 1970. Foeto-maternal transfer and production of cortisol in the sheep. Steroids, 16, 771-789.

DORMER R. A., FRANCE J. T., 1973. Cortisol and cortisone levels in umbilical cord plasma and maternal plasma of pregnancies. Steroids, 21, 497-510.

DUPOUY J. P., CHATELAIN A., 1981. La fonction corticotrope dans la période périnatale: ontogenèse et régulation. J. Physiol. (Paris), 77, 955-968. 
DUVAL M., 1889. Le placenta des rongeurs. J. Anat. Paris, 25, 309-342 et 573-627 et 26, 1-48 et $273-$ 344.

DVORAK M., 1972. Adrenocortical function in foetäl, neonatal and young pigs. J. Endocr., 54, 473-481.

EL HANI A., DALLE M., DELOST P., 1980. Sexual dimorphism in binding and metabolism of cortisol during puberty in the guinea-pig. J. Physiol. (Paris), 76, 25-28.

FAIRCLOUGH R. J., LIGGINS G. C., 1975. Protein binding of plasma cortisol in the foetal lamb near term. J. Endocr., 67, 333-341.

FĖVRE J., 1975. Corticostéroïdes maternels et fœtaux chez la Truie en fin de gestation. C. R. Acad. Sci. (D), Paris, 281, 2009-2012.

GALA R. R., WESTPHAL U., 1967. Corticosteroid-binding activity in serum of mouse, rabbit and guinea-pig during pregnancy and lactation : possible involvement in the initiation of lactation. Acta endocrinol., 55, 47-61.

GAY M., 1976. Evolution de la corticostérone et de l'aldostérone plasmatique et surrénalienne au cours de la période périnatale chez le fatus, le nouveau-né et la mère de Souris. Th. Doct. $3^{\mathrm{e}}$ cycle, Univ. Clermont II, 112 p.

GOLDKRAND J. W., RAYMOND L. M. D., SCHULTE M. D., MESSER R. H., 1976. Maternal and fetal plasma cortisol levels at parturition. Obstet. Gynec., 47, 41-45.

GURPIDE E., 1972. Mathematical analysis for the interpretation of in vivo tracer infusion experiments. Acta endocrinol., 69, suppl. 158, 26-43.

HADJIAN A. J., CHEDIN M., COCHET C., CHAMBAZ E. M., 1975. Cortisol binding to proteins in plasma in the human neonate and infant. Pediat. Res., 9, 40-45.

HILLMAN D. A., GIROUD J. P., 1965. Plasma cortisone and cortisol levels during the neonatal period. J. clin. Endocrinol. Metab., 25, 243-248.

JAFFE R. B., SERON-FERRE M., PARER J. T., LAWRENCE C. C., 1978. Primate fetal pituitaryadrenal axis in the perinatal period. Am. J. Obst. Gynec., 131, 164-170.

JAFFE R. B., SERON-FERRE M., MITCHELL B. F., 1979. Perinatal regulation of cortisol in the primate. J. Ster. Biochem., 11, 549-555.

JOLIVET A., BLANCHIER H., GAUTRAY J. P., 1974. Blood cortisol variations during late pregnancy and labor. Am. J. Obstet. Gynec., 119, 775-783.

JONES C. T., ROEBRUCK M. M., 1980. The development of the pituitary adrenal axis in the guinea-pig. Acta endocrinol., 94, 107-116.

JOST A., 1954. Hormonal factors on the development of the foetus. Cold. Spr. Harb. Symp. Quant. Biol., 19, 167-181.

JOST A., 1957. La physiologie du cortex surrénal fœtal et les interrelations endocrines entre la mère et le fœtus. Bull. Soc. Roy. Belge Gynecol. Obstet., 24, 1-16.

JOST A., 1966. Problems of fetal endocrinology : the adrenal glands. Recent Progr. Hormone Res., 22, 541-569.

KAUFMANN P., DAVIDOFF M., 1977. The guinea-pig placenta. Adv. Anat. Embryol. Cel/ Biol., 53, $1-91$.

KAUPPILA A., KOIVISTO M., PUKKA M., TUILAMA R., 1978. Umbilical cord and neonatal cortisol levels. Obstet. Gynec., 52, 666-672.

KHALDOUN M., 1977. Evolution de l'aldostéronémie et de la cortisolémie chez la jument au cours de la période périnatale et chez le poulain pendant le développement néonatal. Th. Doct. $3^{e}$ Cycle, Univ. Clermont II, 120 p.

KITTINGER G. W., 1974. Foeto-maternal production and transfer of cortisol in the rhesus (Macaca mulatta). Steroids, 23, 229-245.

$\mathrm{KOCH}$ M., 1969. Liaisons de la corticostérone aux protéines plasmatiques et régulation au niveau du stéroïde libre au cours de la gestation et de la lactation chez la Rate. Horm. Metab. Res., 1. 129-135.

KOCH M., LUTZ B., MIALHE-VOLOSS C., STUTINSKY F., 1969. Taux plasmatique et métabolisme de la corticostérone pendant la période postnatale chez le rat. J. Physiol. (Paris), 61, 142-144.

LIGGINS G. C., FAIRCLOUGH R. J., GRIEVES S. A., KENDALL J. Z., KNOX B. S., 1973. The mechanisms of initiation of parturition in the ewe. Recent Progr. Hormone Res., 29, 111-149. 
MALINOWSKA K. W., HARDY R. N., NATHANIELSZ P. W., 1972. Plasma adrenocorticosteroid concentration immediately after birth in the rat, rabbit and guinea-pig. Experientia, 28, 13661367.

MALINOWSKA K. W., NATHANIELSZ P. W., 1974. Plasma aldosterone, cortisol and corticosterone concentrations in the newborn guinea-pig. J. Physiol., (Paris), 236, 83-93.

MARTIN C. E., CARE M. M., HARTMANN P. E., COOK I. F., 1977. Relationship between foetal corticosteroids, maternal progesterone and parturition in the rat. Acta endocrinol, 84, 167176.

MARTIN B., GASC J. M., 1979. Origin of transcortin in the chick embryo. J. Ster. Biochem., 10, 553-556.

MIGEON C. J., BALTIMORE D., 1959. Cortisol production and metabolism in the neonate. J. Pediat., 55, 280-295.

MITCHELL B. F., SERON-FERRE M., HESS D. L., JAFFE R. B., 1981. Cortisol production and metabolism in the late gestation of Rhesus monkey fetus. Endocrinology, 108, 916-924.

MURPHY B. E. P., 1981. Ontogeny of cortisol-cortisone interconversion in human tissues : a role for cortisone in human fetal development. J. Ster. Biochem., 14, 811-817.

MURPHY B. E. P., DIEZ D'AUX R. C., 1972. Steroid levels in the human fetus : cortisol and cortisone. J. Clin. Endocrinol. Metab., 35, 678-683.

MYERS H. I., YOUNG W. C., DEMPSEY E. W., 1936. Graafian follicle development throughout the reproductive cycle in the guinea-pig, with special reference to changes during oestrus (sexual receptivity). Anat. Rec., 65, 381.

OAKEY R. E., 1974. Serum cortisol binding capacity $(C B C)$ of pregnant baboons and their fetuses. 56th Meeting of the Endocrine Society. Abstract $N^{\circ} 451$ (A-281).

OSINSKI P. A., 1960. Steroid 11 $\beta$-ol dehydrogenase in human placenta. Nature, 187, 777.

PAISEY R. B., NATHANIELSZ P. W., 1971. Plasma cortisol levels in the newborn lamb from birth to 30 days. J. Endocr., 50, 701-702.

PATERSON J. Y. F., HILLS F., 1977. The binding of cortisol by ovine plasma proteins. J. Endocr., 37, 261-268.

PEPE G. J., EHRENKRUNZ R. A., TOWRSLEY J. D., 1976. The metabolic clearance rates and interconversion of cortisol and cortisone in pregnant and non pregnant baboons. Endocrinology, 99, 597-601.

REES L. H., JACK P. M. B., THOMAS A. L., NATHANIELSZ P. W., 1975. Role of foetal adreno corticotrophin during parturition in sheep. Nature, 233, 274-275.

RICHET E., SAFWATE A., DAVICCO M. J., DALLE M., BARLET J. P., 1984. Fonction corticosurrénalienne chez le jeune veau, 247-256. In JARRIGE R., Physiologie et Pathologie Périnatales chez les Animaux de la Ferme, INRA, Paris.

ROBINSON J. A., BRIDSON W. E., 1978. Neonatal hormone patterns in the macaque. I. Steroids. Biol. Reprod., 19, 773-778.

SANDBERG A. A., WOODRUFF M., ROSENTHAL H., NIENHOUSE S., SLAUNWHITE W. R., 1964. Transcortin : a corticosteroid binding protein of plasma. VII. Half-life in normal and estrogentreated subjects. J. clin. Invest., 43, 461-466.

SAVU L., NUNEZ E., JAYLE M. F., 1977. Corticosterone binding by mouse during fetal and postnatal development. Acta endocrinol., 84, 177-190.

SEAL U. S., DOE R. P., 1967. The role of CBG in mammalian pregnancy, 697-706. In Hormonal steroids. Proc. 2nd int. Congr., Excerpta Med. Found., Amsterdam.

SERENI F., CASTEGNARO E., PERLETTI L., SALA G., 1966. Cortisol metabolism by the isolated and perfused newborn rabbit liver. J. Endocr., 35, 13-17.

SERON-FERRÉ M., MITCHELL B. F., LAURENCE C. C., JAFFE R. B., 1978. Regulation of the primate adrenal gland in the perinatal period. Endocrinologie perinatale et parturition. Les Colloques de I'INSERM, INSERM, vol. 77, 13-22.

SHAPIRO S., PERCIN C. J., KOTICHAS F. J., 1971. Half-life of plasma corticosterone during development. Endocrinology, 89, 284-286.

STEVENS J., 1970. Plasma cortisol levels in the neonatal period. Arch. Dis. Child., 45, 592-594.

VAN BAELEN H., VANDOREN G., DE MOOR P., 1977. Concentration of transcortin in the pregnant rat and its foetuses. J. Endocr., 75, 427-431. 
VILLEE D. B., ENGEL L., LORING J., VILLEE C., 1961. Steroid hydroxylation in human fetal adrenals : formation of $16 \alpha$-hydroxy-progesterone, $17-\mathrm{OH}$ progesterone and desoxycorticosterone. Endocrinology, 69, 345-372.

WESTPHAL U., 1971. Steroid-protein interactions. In GROSS F., LABHART A., MANN T., SAMUELS L. T., ZANDER J., Monographs on endocrinology, Berlin, Heidelberg, New York, Springer Verlag.

WINTOUR E. M., BROWN E. H., DENTON D. A., HARDY H. J., McDOUGALL J. G., ODDIE C. J., WHIPP G. T., 1975. The ontogeny and regulation of corticosteroid secretion by the ovine foetal adrenal. Acta endocrinol., 79, 301-316.

WÜSTENFELD E., KATTNER W., 1968. Karyometriche Untersuchungen an foetalen und postpartalen Nebennieren (Meerschweinshen). Z. Mikrosk. Anat. Forsch., 79, 93-119. 